\title{
Sosyal Girişimlerin Örgütsel Kimlik Yoluyla Meşruiyet Arayışları
}

\author{
Hava YAŞBAY KOBAL ${ }^{1}$

\section{$\ddot{O} z$}

Araştırmanın amacı, Türkiye'de sosyal girişimlerin örgütsel kimlik örüntüsünü ortaya çıkarmak ve örgütsel kimlik aracılığıla ile ne tür bir meşruiyet elde etme çabası içinde olduklarını araşıtırmaktır. On üç sosyal girişimci ile yapılan görüşmelerden elde edilen veriler NVivo 12 nitel veri analizi programında analiz edilmiştir. Sonuçlar, örneklemde yer alan sosyal girişimlerin merkezi özelliklerinin sosyal misyon teması altında toplandığını göstermektedir. En sık vurgulanan kelimelerin de sosyal misyon temasını destekler nitelikte "kadın" ve "sosyal" kelimeleri olduğu saptanmıştır. Örneklemde yer alan sosyal girişimlerin ayırt edici özellikleri "samimiyet" ve "kapsayıcıllk" kavramları ile benzer özelliklerinin ise "sosyal fayda" ve "organik örgüt yapısı" ile tanımlandığı saptanmıştır. Analiz sonucunda sosyal girişimlerin süregelen özellikleri "paylaşım", "yenilik" ve "iyilik" gibi kavramlar alında toplanmışır. Araştırmanın meşruiyet ile ilgili sonuçlarına bakıldığında sosyal girişimlerin meşru bir örgüt kimliği inşa etmelerinin daha çok bilişsel meşruiyet ve daha sonra ahlaki meşruiyet elde etmelerine yarar sağlayacağı tespit edilmiştir.

Anabtar Kelimeler: Örgütsel Kimlik, Meşruiyet, Sosyal Girişim, Sosyal Girişimcilik

\section{Social Enterprises' Quest for Legitimacy through Organizational Identity}

\section{Abstract}

The aim of the study of social enterprises in Turkey, is to reveal the patterns of organizational identity and that they are investigating them in an effort to obtain a kind of legitimacy with through organizational identity. The data obtained from interviews with thirteen social entrepreneurs were analyzed in NVivo 12 qualitative data analysis program. The results show that the central characteristics of the social enterprises in the sample are gathered under the social mission theme. The most frequently emphasized words were found to be "woman" and "social", supporting the social mission theme. The distinctive features of social enterprises in the sample are expressed in terms of "sincerity" and "inclusiveness". Therefore, it can be stated that the characteristics that social enterprises use to distinguish themselves from others are gathered around the same concepts. Similar characteristics of social enterprises are defined by "social benefit" and "organic organizational structure". As a result of the analysis, the ongoing characteristics of social enterprises were collected under concepts such as "sharing", "innovation" and "goodness". Considering the results of the research regarding legitimacy, it has been determined that social enterprises' establishment of a legitimate organizational identity would benefit them to gain more cognitive legitimacy and then moral legitimacy.

Key Words: Organizational Identity, Legitimacy, Social Enterprise, Social Entrepreneurship

\section{Atıf İçin / Please Cite As:}

Yaşbay Kobal, H. (2022). Sosyal girişimlerin örgütsel kimlik yoluyla meşruiyet arayışları. Manas Sosyal Araștırmalar Dergisi, 11(1), 259-274.

Geliş Tarihi / Received Date: 27.03.2021

Kabul Tarihi / Accepted Date: 28.06.2021

\footnotetext{
${ }^{1}$ Dr. Öğr. Üyesi - Hakkari Üniversitesi, havayasbay@hakkari.edu.tr 


\section{Giriş}

Bir örgütün kimliği faaliyet gösterdiği bağlamda oluşur. Kurumsal ortamda, örgütün kimlik meșruiyeti, kurumsal normlara, değerlere ve düzenlemelere uygunluğuyla belirlenmektedir (He ve Baruch, 2009, s. 592). Örgütsel kimlik, kurumsal kuram literatüründe örtük bir tema olmaya devam etmektedir ve meşruiyetle ilişkilendirilen kimlik niteliklerine ilişkin az sayıda araştırma (Bridwell-Mitchell ve Mezias, 2012; Clegg vd., 2007; Dutton ve Dukerich, 1991; Elsbach ve Sutton, 1992; Elsbach ve Kramer, 1996; Fiol vd., 1996; Chreim, 2000; Foreman ve Whetten, 2002; He ve Baruch, 2009) yapılmıştır. Dolayısıyla daha fazla araştırmayı hak eden önemli bir alandır (Brown, 2001, s. 117). Araştırmalar genellikle örgütü tanımlayan kalıcı bir öz olarak kimliğe odaklanmıştır. Her ne kadar 'kimlik' kelimesi kullanılmasa da kurumsal kuram tartışmaları örgütlerin kendilerini diğer örgütlere göre nasıl tanımladıkları açısından kimliğe dikkat çekmiştir (DiMaggio ve Powell, 1983).

Tıpkı insanlar gibi örgütler de yerleşik bir düzene göre çalışırlar; aksi takdirde savundukları kimlik bir anlam ifade etmeyecektir. Gelişmekte olan sektörler gibi böyle bir düzenin kurulmadığ1 yerlerde, örgütler kendileri için bir düzen inşa etmelidirler (Aldrich ve Fiol, 1994, s. 648). Lounsbury ve Glynn, 2001, yeni bir girişimci örgütün kimliğinin, çeşitli paydaşlar tarafindan verilebilecek meşruiyetin mihenk taşı olarak hizmet edebileceğini ifade etmektedir (He ve Baruch, 2009, s. 592). Buradan hareketle, çalışmanın amacı, Türkiye'de gelişmekte olan bir sektör olan sosyal girişimlerin, üst yönetim aracıllğ̆yla nasıl bir kimlik oluşturdukları ve örgütsel kimlik ile ne tür bir meşruiyet elde etme çabası içinde olduklarını araştırmaktır.

\section{Örgütsel Kimlik}

Cheney (1991), İngilizcede kimlik anlamına gelen "identitiy" kelimesinin kökeninin, farklı bireylerdeki aynılıktan söz etmek için Latince'de identitas- kelimesini türeten Aristoteles'e kadar izlenebileceğini belirtmektedir. Aristoteles'e göre, aynı ebeveynden doğan kardeşler birbirlerinin aynısıdır; ancak ayrı bireylerdir. Yine de Aydınlanma Çağı'ndan beri kişinin kimliği, kendisini diğerlerinden ayıran ve bu "benliği" benzersiz kilan anlam olarak tanımlanmıştır (Thoger Christensen ve Cheney, 1994, s. 224; Chreim, 2000, s. 5-6).

Yönetim bilim adamlarının kimliğe olan ilgisi 1985 'ten önceki zamanlara dayanmaktadır. Balmer (1994), 1950’lerde ABD'de șirketlerin logoları etrafında kimlik sorunlarına ilgi duyulduğunu ifade etmiştir. Pazarlama alanında başlayan bu ilgi daha sonra örgütün kendisini dış kitlelere nasıl ifade ettiğini kapsayacak şekilde yönetim ve organizasyon alanında genişletilmiştir. Literatürde ilk olarak Blau ve Scott'un (1962) çalısmalarında bir kimliği olan örgütlerden bahsedildiği ifade edilse de Selznick (1957)'in örgütlerin de bir kimliği olduğuna dair fikri, kurumsallaşma hakkındaki klasik çalısmasında da yer almaktadır. Selznick'in (1957) kurumsallaşmış örgütünde kimlik, örgüte ayırt edici bir özellik kazandırmaktadır. Kimlik, kurumsallaşma sürecinin tarihsel bir üründür. Blau ve Scott (1962) ve Selznick (1957) kimlik kavramını kullanmalarına rağmen, konu hakkında daha derinlemesine çalışmaların yapılması uzun zaman almıştır. $\mathrm{Bu}$ anlamda örgütsel kimlik kavramına dair akademik ilginin başlangıç noktası olarak Albert ve Whetten'in (1985) “Organizational Identity” isimli çalışması gösterilmektedir. Makale örgütsel kimlik kavramının ilk defa kapsamlı olarak ele alınmasını sağlamış ve sıkça atıfta bulunulan bir tanım sunmuştur (Brunninge, 2005, s. 12-13).

Albert ve Whetten'e (1985, s. 263) göre örgütsel kimlik, bir örgütün üyeleri tarafindan örgüt hakkında en merkezi, ayırt edici ve kalıcı olarak algilanan özelliklerdir. Daha genel olarak örgütsel kimlik örgütlerin "Biz kimiz?" sorusuna verdikleri yanıt olarak tanımlanmaktadır. Bu soruya verilecek cevaplar aşağıdaki üç özelliğin tümünü karşılamalıdır (Whetten ve Godfrey, 1998, s. 21; Gioia, Majken ve Kevin, 2000, s. 63-64; Whetten ve Mackey, 2002, s. 394; Foreman ve Whetten, 2002, s. 618; Corley, 2004, s. 1146-1147; Brunninge, 2005, s. 11; Corley vd., 2006, s. 87):

1. Örgüt üyelerine göre örgütün merkezi/temel özelliği

2. Örgütü diğer örgütlerden ayıran özellikler

3. Örgütün geçmişle (ve muhtemelen gelecekle) bağını devam ettiren kalıcı veya devam eden özellikleridir.

Örgütsel kimlik yöneticilerin zihninde belirlendiği süreçler, faaliyetler ve olaylar ile oluşturulmaktadır. Üst düzey yöneticiler örgütün farklı ve kalıcı özellikleri için istediği görüntüyü yansıtmaya çalışmaktadır (Scott ve Lane, 2000, s. 44-45; Bridwell-Mitchell ve Mezias, 2012, s. 203). 


\section{Merkezilik}

Merkezilik, kolayca değişebilen yüzeysel özellikler ile köklü temel özellikler arasında bir ayrımı gerektirmekte, kimlik özelliklerinin açıça görülmeyen ve derin köklerde yer alan özünü ifade etmektedir. Merkezi özellikler örgüt üyelerinin genellikle örgüt için gerekli olduğunu düşündükleri, bunlar olmadan farklı bir örgüt türü olurduk şeklinde nitelendirdikleri özelliklerdir (Whetten ve Mackey, 2002, s. 395; Corley, Harquil, Pratt, Glynn, Fiol ve Hatch, 2006, s. 91; Whetten, 2006, s. 222; He ve Baruch, 2009, s. 577). Albert ve Whetten (1985), yöneticilerin kimlik sorusuna cevap vermeleri istendiğinde merkezi niteliklerin bir sınıflandırmasına başvurduklarına işaret etmektedir (Chreim, 2000, s. 14). Merkezilik, örgütün yaptığı iş, temel amacı ve misyonu ile yakından ilgilidir (McMillan, 1987, s. 38 Akt: Ağlargöz, 2011, s. 17).

\section{Farkl111k}

Farkllık, örgütün kimliğini kendi alanındaki veya sektörlerindeki diğer örgütlerle karşılaştırarak yorumlamasıdır. Dolayısıyla farklılık, karşılaştırmaya, benzer ve ayırt edici özellik yargılarına dayanmaktadır. Bireyler, kendi örgütlerini diğer örgütlerle karşılaştırır; onu benzer diğerlerinden ne ölçüde farklılaştırdığını göz önünde bulundurur (Corley vd., 2006, s. 92; Whetten, 2006, s. 222; He ve Baruch, 2009, s. 577). Ancak burada bir örgüt, diğer örgütlerin de kullanabileceği sınırlı sayıda kategoriyi kullanabilir. Martin vd. (1983)'nin öne sürdüğ̈ gibi, bir örgütün benzersizlik iddiası, benzersiz olmayan tezahürlerle paradoksal olarak ifade edilir. Eşsiz olduğunu iddia eden yedi tür öykü üzerinde yaptıkları çalışmada, bu tür öykülerin çeşitli örgütlerde aynı biçimde ortaya çıtığını göstermişlerdir. Farklılık, kişilerin adlanı, hangi rozetlerin takıldığ1, eylemin nerede gerçekleştiği gibi örgüte özgü ayrıntılarla pekiştirilmiştir (Chreim, 2000, s. 16-17).

\section{Geçici Süreklilik}

Geçici süreklilik, "zaman içindeki aynıllk" anlamına gelmektedir (He ve Baruch, 2009, s. 577). Örgütsel kimliğin geçici sürekliliği, bir örgütün kimliğinin yalnızca örgütsel yaşamdaki büyük değişimler nedeniyle değişmesini ifade etmektedir. Bu nedenle Albert ve Whetten (1985), örgütsel kimlikteki değişikliklerin çok yavaş, uzun zaman dilimleri içinde gerçekleştiğini belirtmiştir (Corley vd., 2006, s. 93; Whetten, 2006, s. 222; Gioia ve Thomas, 1996, s. 402).

Kimliğin değişken doğasını incelerken, kalıcı bir kimlik ile sürekliliğe sahip bir kimlik arasında ayrım yapmak yararlıdır. Ashforth ve Mael (1996) bu iki kavramı eşanlamlı olarak görürken, farkın ince, ancak teorik olarak önemli olduğunu belirtmektedir. Kalıc bir kimlik kavramı, kimliğin zaman içinde aynı kaldığını ifade etmektedir. Bununla birlikte, süreklilik duygusuna sahip bir kimlik, zaman ve bağlam içinde genişleyen "temel" değerlerini korurken yorumunda ve anlamında değişen bir kimliktir. Örneğin, "Hizmet için varı!!" veya "Biz yenilikçi bir örgütüz" sözleri, farklı zamanlarda farklı gruplar için farklı şeyler ifade eder. Bu nedenle, çekirdek sabit görünmesine rağmen akış halindedir (Gioia vd., 2000, s. 65).

Örgütsel kimlik araştırmaları büyük ölçüde sosyal kimlik teorisine dayanmaktadır. Buna göre insanlar kendilerini ve diğerlerini çeşitli sosyal veya demografik gruplara (örneğin cinsiyet, rrk, etnisite, din, meslek vb.) göre sinıflandırmaktadır. Bu sosyal sınıflandırma şeması, bireylere kendilerini birlik duygusu veya belirli bir grupla özdeşleşme duygusu yoluyla tanımlamalarını sağlamaktadır. Örgütsel kimlik esasen sosyal kimliğin bir alt türü olarak görülebilir (Foreman ve Whetten, 2002, s. 619). Örgütler istikrarlı bir kimlik yaratmaya, "konumlarını meşrulaştırmaya ve söylem yoluyla kimliklerini inşa etmeye" çalışıllar. Bu tür bir meşruiyet, "varlığın eylemlerinin sosyal olarak oluşturulmuş normlar, değerler, inançlar ve tanımlar sistemi içinde arzu edilir ve uygun olduğuna dair genel bir alg1 veya varsayım" olarak kabul edilebilir (Suchman 1995, s. 574).

\section{Meşruiyet}

Kurumsal kurama göre, meşruiyet, paydaşlar örgütün hedeflerini ve faaliyetlerini onayladığında ve desteklediğinde kazanılmaktadır ve örgüt meşru bir itibara sahip olduğu için ödüllendirilmektedir (DiMaggio ve Powell, 1983; Pfeffer ve Salancik, 1978). Dolayısıyla, bir örgütün, araçlarının ve amaçlarının sosyal normlara, değerlere ve beklentilere uygun olduğu ölçüde meşru olduğu ifade edilebilir (Ashforth ve Gibbs, 1990; Foreman ve Whetten, 2002).

Suchman (1995, s. 574), meşruiyeti "sosyal olarak oluşturulmuş normlar, değerler, inançlar ve tanımlardan oluşmuş bir sistem içinde var olan bir oluşumun eylemlerinin istenilen, düzgün ve uygun 
olduğu yönündeki genel alg1 veya varsayım" olarak tanımlamakta; meşruiyet türlerini "pragmatik meşruiyet", "ahlaki meşruiyet" ve "bilişsel meşruiyet" olarak üç sınıfa ayırmaktadır.

\section{Pragmatik Meşruiyet}

Pragmatik meşruiyet örgütün yakın çevresinde yer alanların kendi çıkarlarına yönelik hesaplarına dayanmaktadır ve en basit düzeyde, bir değişim meşruiyeti olarak ifade edilebilir (Suchman, 1995, s. 578). Dolayısıyla pragmatik meşruiyet, örgütü değerlendiren grupların kişisel çıkarları ile ilgilidir (Johnson ve Holub, 2003, s. 272). Söz konusu çevre unsurları örgüt faaliyetlerinin pratik sonuçlannı belirlemek için örgütsel davranış1 inceleyen bir seçmen gibi davranmaktadırlar (Suchman, 1995, s. 578). Devletin temsilcileri ve mesleki dernekler bu anlamda genellikle kritiktir. Bu örgütler tarafindan sağlanan sertifikalar veya akreditasyon, meşruiyetin bir göstergesi olarak sıklıkla kullanılmaktadır (Scott, 2001, s. 46).

\section{Ahlaki Meşruiyet}

Ahlaki meşruiyet, örgüte ve faaliyetlerine ilişkin olumlu bir normatif değerlendirmeyi yansıtmaktadır. Pragmatik meşruiyetten farklı olarak bir faaliyetin değerlendiriciye fayda sağlayıp sağlamadığına ilişkin yargılara değil, faaliyetin "yapılacak doğru şey" olup olmadığına ilişkin yargılara dayanmaktadır (Suchman, 1995, s. 579). Ahlaki meşruiyet, "daha büyük kültürel kuralların" ifadesidir ve örgütün daha geniş bir toplumsal kesim tarafindan kabul görmüş normlara, standartlara ve değerlere uyumlu hareket ettiğinin bir göstergesidir. Dolayısıyla, dar kişisel çıkarlardan farklı olarak toplumsal bir mantığı yansıtmaktadır (Suchman, 1995, s. 579-580; Bitektine, 2008, s. 31).

\section{Bilişsel Meşruiyet}

Bilişsel meşruiyet çıkar ya da değerlendirmeden ziyade biliş temeline dayanmaktadır. Burada olumlu ya da olumsuz şeklinde bir değerlendirme yapılmadan örgüt faaliyetlerinin ve amaçlarının toplum tarafindan doğru, beklentilere uygun olarak kabulü söz konusudur. Bu açıdan bilişsel meşruiyeti kazanan örgüt doğruluğundan şüphe edilemez olarak kabul edilmektedir (Suchman, 1995, s. 582-583). Bilişsel alanda, kolektif eylem genellikle popülerleşmenin ya da standardizasyonun artması ile gerçekleşmektedir (Suchman, 1995, s. 592). Bu standart ve popüler formlara uyum sonucunda örgüt faaliyetleri toplumun nezdinde daha öngörülebilir, daha anlamlı ve daha cazip hale gelmektedir (Suchman, 1995, s. 582).

\section{Örgütsel Kimlik ve Meşruiyet}

Kurumsal kuram, örgütsel kimliğin toplumsal olarak kurumsallaşmış kategoriler temelinde ve izomorfik süreç yoluyla inşa edildiğini ileri sürmektedir (He ve Baruch, 2009, s. 575-76). Bir kimliğe sahip olmak eylemler için meşruiyet talep etme yeteneği sağlamakta, kazanılan meşruiyet, varllğın toplumsal kaynaklar üzerinde hak iddia etme yeteneğini artırmaktadır (Levitt, 1994, s. 236).

Glynn ve Abzug (2002), örgütsel kimliğin kurumsal çevre ile güçlü bir etkileşime sahip olduğunu ve bunun da örgütün meşruiyet oluşturmasına ve sürdürmesine yardımcı olduğunu ifade etmektedir (He ve Baruch, 2009, s. 580). Örgütsel kimlik, tutumları ve eylemleri rasyonelleştirerek varllğın bir sosyal kategori içine yerleştirilmesine izin verir, bu da davranışın tahmin edilmesini ve meşru davranış1 neyin oluşturduğunun tanımlanmasını sağlar (Chreim, 2000, s. 6; Bridwell-Mitchell ve Mezias, 2012, s. 192). Dolayısıyla örgütlerin kimlikleri, devam eden meşruiyet arayışlarında kilit kaynaklardır (Sillince ve Brown, 2009, s. 1830). Carpenter (1994), aynı sektörde faaliyet gösteren örgütlerin kimlik beyanının sektör özelliklerini paylaştıklarını belirtmektedir. Dolayısıyla, örgütleri bir dizi nitelik üzerinde bir araya getirmeye yönlendiren kurumsal ve endüstriyel güçler olduğu ifade edilebilir (Chreim, 2000, s. 16).

Örgütsel kimlik, örgütsel etkinliklere anlam katan bir dizi bilişsel kategori sağlayarak örgütsel etkinliklerin anlamlı olmasını sağlamaktadır. Bu, örgütsel kimliğin bilişsel meşruiyet için bilişsel bağlam olduğu anlamına gelmektedir. Örneğin, çalışanlar, "topluma hizmet eden bir örgütüz" veya "cömert ikramiyeler sağlayan bir örgütüz" gibi tanımlara sahip olabilir. Örgütsel kimlik durumunda, bu özellikler bilişsel meşruiyetin temeli olan örgütü tanımlamak ve sınıflandırmak için kullanılır. Örgütsel kimlik, bir örgütün etikliği ve paydaşlara sunduğu değişim veya araçsal değerle ilgili özelliklere sahip olabilir. Dolayısıyla, örgütsel kimliğin ahlaki ve pragmatik meşruiyetle de ilgili olduğu ileri sürülebilir. Ahlaki ve pragmatik meşruiyet için, stratejiler sırasıyla örgütün faaliyetlerinin etik temelini veya araçsal değerini oluşturmaya odaklanmaktır. Bilişsel meşruiyet için stratejiler ise örgüt faaliyetlerinin tanımını ve anlamını oluşturmaya yöneliktir (Bridwell-Mitchell ve Mezias, 2012, s. 192-195). 
Yeni sektörlerde meşruiyetin yaratılması, girişimcilerin sembolik dil ve davranışı kullanma kapasitesinin yanı sıra ne yaptıkları ve bunu neden yaptıkları hakkında tutarlı hikayeler iletme yetenekleriyle bağlantılıdır (Clegg, Rhodes ve Kornberger, 2007, s. 515-516). Literatürde çok sayıda yazar (Barnard, 1938; Selznick, 1957; Lyles ve Schwenk, 1992; Pettigrew, 1979; Pfeffer, 1981; Pondy, 1978; Smircich ve Morgan, 1982) örgütler için anlam yaratmada liderlerin ya da üst yönetimin rolünü vurgulamıştır (Chreim, 2000, s. 10). Buna göre üst yönetimin gözünde bir örgütü diğer örgütlerden ayıran misyonlar, uygulamalar ve değerler örgütsel kimliklerin şekillenmesine katkıda bulunmaktadır (Scott ve Lane, 2000, s. 44-45; Pratt ve Foreman, 2000, s. 36-37). Diğer taraftan örgütsel kimlik alanındaki mevcut çalışmalar (Ashforth ve Gibbs, 1990; Elsbach ve Kramer, 1996) genellikle meşruiyet kazanmak yerine yöneticilerin onarım çabalarına odaklanmıştır. Ancak, bir stratejist ve makro aktör olarak üst yönetim örgütsel kimliğin oluşturulmasında etkili bir aktör olmaya devam etmektedir (Chreim, 2000, s. 11). Bu nedenle bu çalışmada örgütlerin kimlik ve meşruiyet elde etme çabaları üst düzey yöneticilerin bakış açısından ele alınacaktır.

\section{Örgütsel Kimlik ve Meşruiyet İlişkisine Yönelik Literatür}

Dutton ve Dukerich (1991, s. 517-542), New York/New Jersey Liman İdaresi'nin, işlettiği tesislerde bulunan evsizlerin sayısının artması sorununu nasıl tanımladığına ve buna nasıl yanıt verdiğine ilişkin modelin oluşturulmasında örgütsel kimliğin oynadığı role odaklanarak 1982-1989 yılları arasını konu alan bir vaka çalışması yapmışlardır. Görüşmecilere örgütlerini ayırt eden özellikler ile ilgili görüşleri sorulmuş ve New York/New Jersey Liman İdaresi’nin örgütsel kimlik özellikleri ortaya konmuştur. Katılımciların tamamı Liman İdaresini benzersiz teknik uzmanlığa sahip, sosyal hizmet faaliyetlerine uygun olmayan profesyonel bir örgüt olarak tanımlamıstır. Katılımcıların \%44’ü örgütlerinin etik ve fedakar; \%36'sı yüksek kaliteli bir örgüt ve üstün hizmet sağlayıcısı olduğunu ifade etmiştir. Yazarlara göre, bir örgütün kimliği zaman içinde örgütsel eylem kalıplarını etkilemektedir.

Elsbach ve Sutton (1992), örgüt üyelerinin yasadışı eylemlerinin kilit seçmenlerin onayına ve desteğine nasıl yol açabileceği ile ilgili bir çalısma yapmışlardır. İki sosyal hareket örgütünün (Önce Dünya! ve Gücü Açığa Çıkarmak için AIDS Koalisyonu (ACT UP)) gayri meşru faaliyetlerinin bu örgütler için meşruiyet ikilemleri yarattığı görülmüştür. Bir yandan, kültürel açıdan gayri meşru faaliyetler, üyeleri uzaklaştıran ve dış desteği tehlikeye atan olumsuz yorum ve saldırılara neden olabilirken öte yandan ortaya çıkan kimlik, örgütün bu tür yasadışı eylemleri destekleyen çok dar toplum kesimleri içindeki itibarını güçlendirebilmektedir. Ayrıca, bu tür bir kimliğin, doğru yönetilirse örgütün kültürel olarak kabul edilebilir amaçlarını destekleyen nispeten geniş toplum kesimlerinin meşruiyetini kazanmasını sağlayabileceği sonucuna ulaşılmıştır (Elsbach ve Sutton, 1992, s. 733).

Elsbach ve Kramer (1996, s. 451), ABD’nin "En İyi 20 İşletme Okulu” sıralamasının işletme okullarının örgütsel kimlikleri üzerindeki etkilerini araştırmışıır. İşletme okullarının kalıcı kimlik boyutlarının güvenilir bir tanımını elde etme girişiminde, benzersiz ve tanımlayıcı özelliklere ilişkin ifadeler için örgütsel kayıtları- yani beş yıl boyunca okulların kayıtlarını - araştırmıştır. Ortaya çıkan kimlik boyutlarını şöyle listelemişlerdir. Kültür türü (katıllımcı kültür; küçük / dost kültür), değerler (akademik değerler; iş etĭği), öğrencilerin türü (farklı öğrenciler; seçkin öğrenciler), program türü (küresel program; nicel program), kurum türü (kamu kurumu), yaklaşım (girişimci; teknik) ve ünlü üniversite ve güçlü mezunlar. Çalışmanın sonunda katılımcıların Business Week En İyi 20 İşletme Okulu sıralamasını örgütsel kimliklerine yönelik bir tehdit olarak algıladıkları görülmüştür (Elsbach ve Kramer, 1996, s. 453).

Fiol vd. (1996) ABD’deki Baby Bells veya bölgesel Bell işletme şirketleri (RBOC'ler) ile yaptıkları çalışmada örgütsel kimliğin evrimini araştırmada iki sorunun etkili olduğunu kanıtlamışlardır: 1) Örgütünüzü diğer RBOC'lere kıyasla tanımlamak için hangi kelimeleri kullanırsınız? 2) Örgütünüzü rakiplere kıyasla tanımlamak için hangi kelimeleri kullanırsınız? 5'li Likert ölçeğinde ölçülen anket maddeleri, saldırganlık derecesi, stratejik odaklanma, müşteri odaklılık, risk toleransı, bürokrasi, maliyet yapis1, hareket hızı ve kısıtlama olarak saptanmıştır (Chreim, 2000, s. 36).

Chreim (2000), üst yönetim söyleminde kimlik geliştirme sürecini değişim bağlamında araştırmak için, 1985-1997 yılları arasında Kanadalı iki yetkili banka için yönetim söyleminin boylamsal bir analizini yapmışlardır. Sonuçlar, örgütsel kimliğin kalıcı olmaktan çok gelişmeye ve değişmeye yatkın olduğunu göstermektedir. Bir kimlik temasının merkeziliğindeki bir değişikliğin, temayla ilişkili niteliklerin kümesinde bir değişikliği işaret ettiği saptanmıştır. Çalışmanın bulguları, sürekliliğin değişim bağlamında nasıl kurulduğuna da işaret etmektedir. Bu çalışmada, sürekliliği korumanın bir yolunun, örgütü inovatif olarak tanımlamak olduğu, saptanmıştır. Bu da örgütün bir taraftan kalıcı bir öz tanımlamayı sürdürürken diğer 
taraftan farklı değişiklikler de yapabildiği anlamına gelmektedir. Diğer sürekliliği sürdürme stratejileri, yıllar boyunca aynı tanımlamaları kullanmayı içermektedir. Bu tanımlar zamanla farklı anlamlar ifade etmeye başlasalar da kalıcıdır. Bulgular, incelenen iki örgütün esasen günümüze demirlendiğini, geçmişten gelen kalıcı tanım kullanımı ve söylemde sürekliliğin sağlandığını göstermektedir (Cheriem, 2000, s. 171-172).

Wellefor ve Dudley (2000) ABD Virjinya'da yer alan Total Action Against Poverty (TAP) adinda bir sivil toplum örgütünde örgütsel kimliği betimlemeye yönelik durum çalısması yapmışlardır. Yazarlar "kelime frekansı" yöntemi ile ilk olarak üst yöneticinin örgütü tanıtmak amacıyla potansiyel bağışçlara yazdığ1 metinde yer alan TAP'ın kimliğine ilişkin 33 kelime saptamışır. Daha sonra bu kelimelerin tarihsel süreç ve çeşitli örgüt paydaşları açısından da geçerli olup olmadığı analiz edilmiştir. Tarihsel açıdan bu kelimelerin çeşitli örgüt paydaşları açısından da büyük ölçüde geçerli olduğu ve dolayısıyla örgütsel kimliğin korunduğu sonucuna ulaşılmıstır.

Foreman ve Whetten'in (2002) çalışması ilk olarak, bir kimliğin ne olarak algıladığı ile ne olması gerektiği arasında bilişsel bir karşılaştırma modeli sunmaktadır. İkincisi, örgütsel kimliği çoklu ve rekabet eden kimlikler açısından işlevsel hale getirerek mevcut düşünceyi genişletmektedir. Oluşturulan model, hem "iş" hem de "aile" kimliklerinin unsurlarından oluşan "melez" bir kimlik formundaki kırsal kooperatiflerin üyelerinden elde edilen veriler yoluyla test edilmektedir. Analiz sonuçları, örgütsel kimlik uyumunun örgütsel bağllık üzerinde ve hem bilişsel hem de pragmatik meşruiyet üzerinde önemli bir etkiye sahip olduğunu göstermektedir. Örgüt üyeleri kimlik algılarını ve beklentilerini bilişsel olarak karşılaştırırlar ve ortaya çıkan kimlik uyumu düzeyi, örgütsel bağlllık düzeylerini önemli ölçüde etkilemektedir (Foreman ve Whetten, 2002, s. 618-628).

Örgütsel kimliğin, en iyi zamansal farklllı (zaman içinde istikrarlı bir kimliğin performansı) ve mekânsal farklılık (örgütsel kimliğin diğer örgütlerle ilişkili olarak konumlandırılması) arasındaki ilişki açısından anlaşıldığını savunan Clegg vd.'ne (2007, s. 495) göre meşru bir örgütsel kimlik inşasını mümkün kılan şey, bu iki farklılık biç̧imi arasındaki ilişsidir. Avustralya'da gelişmekte olan işletme koçluğu sektöründen elde edilen veriler analiz edilmiştir. Analiz sonuçları şu şekildedir: İşletme koçları kendi kimliklerini söylemsel olarak inşa etmeye çalışmışardır. Zamansal olarak sabit, ancak bunu, kendilerini diğerleriyle aynı ve farklı olma açısından mekansal olarak tanımlayarak yapmışlardır (Clegg vd., 2007, s. 511-512). İşletme koçları kendilerini ısrarla ne olduklarına göre değil ne olmadıklarına göre tanımlamışlardır. İşletme koçları mekansal ve zamansal stratejiler ve kaynaklar kullanarak istikrarlı bir kimlik yaratmaya ve "konumlarını meşrulaştırmaya ve söylem yoluyla kimliklerini inşa etmeye" çalışışlardır (Clegg vd., 2007, s. 515).

He ve Baruch (2009) İngiltere inşaat şirketlerinde kurumsal değişim sırasında örgütsel kimliğin nasıl değiştiğini araştırmıştır. Makalenin bulguları şu şekilde özetlenebilir: kurumsal değişim (özellikle düzenleme ve uygulama değişiklikleri) kimlik sorunlarının, yani kimlik belirsizliği, meşruiyet krizi ve kimlik eskimesinin tetikleyicisi olarak hizmet etmektedir. Dolayısıyla örgütsel kimlik değişimi kurumsal değişim tarafindan tetiklenebilir. Liderlik, örgütsel kültür ve stratejik uygulamalar dış baskının neden olduğu kimlik sorunlarının üstesinden gelmek için göze çarpan araçlardır. Kurumsal değişim, yönetilmesi gereken algılanan bir meşruiyet krizi yaratmış, yeni bir kimliğin oluşumu, meşruiyet yönetimi ile kolaylaşmıştır. Bununla birlikte, bu durum örgütler arası kimlik farklılaşmasını azaltmış ve sektör kimliğini güçlendirmiştir. Bazı inşaat şirketleri, sektör içinde nispeten daha farklı bir kimliğe duyulan ihtiyacı fark etmiştir (He ve Baruch, 2009, s. 591).

Bridwell-Mitchell ve Mezias (2012) çalışanların örgütsel kimlik anlayışlarının yönetimsel iletişim stratejileri tarafından ne ölçüde dönüştürülebileceğini anlamak için kavramsal bir çerçeve sunmaktadır. Çalışanların örgütsel kimlik anlayışlarındaki dönüşümün meşruiyet yönetimi alanına özgü iletişim stratejileri kullanan yöneticilere bağlı olduğunu iddia etmişlerdir. Çalışmada yöneticilerin, çalışanların örgütsel kimliğini ve meşruiyet endişelerini yöneterek yeni girişimler için nasıl bilişsel meşruiyet kazanabileceği incelenmiştir. Araştırma sonucunda, yöneticilerin meşruiyet kazanmak için gelecek vaadleri, soyut anlam ve etki üreten vaadleri, kimlik belirsizliğini azaltan, kimliği geliştiren olumlu iddiaları kullandıkları sonucuna ulaşılmışır.

\section{Yöntem}

Keşif amaçlı bu çalışmada gömülü teori (grounded theory) yaklaşımı benimsenmiştir (Glaser ve Strauss, 1967; Miles ve Huberman, 1984; Eisenhardt, 1989; Strauss ve Corbin, 1990, 1998). Gömülü teori yaklaşımı yeni teori oluşturarak veya mevcut teoriye ilaveler yaparak teoriyi ilerletmeyi amaçlamaktadır ( $\mathrm{He}$ 
ve Baruch, 2009, s. 581). Strauss ve Corbin'e (1990, s. 37) göre bu yaklaşımın altında yatan ana varsayım incelenen fenomenle ilgili tüm kavramların tanımlanmamıs olması veya tanımlanmışlarsa "kavramsal olarak az gelişmişlerdir" Ayrıca, gömülü teori yaklaşımında araştırma sorusu bağımlı ve bağımsız değişken arasındaki ilişkiler hakkında ifadeler gerektirmez, çünkü amaç bir hipotezi test etmek değildir. Araştırma sorusu, incelenecek olguyu tanımlayan bir ifadedir (Strauss ve Corbin, 1990, s. 38). Bu nedenle, veri toplama, analiz ve teori birbirleriyle karşıllıklı ilişsi içindedir. Kişi bir teoriyle başlayıp sonra onu kanıtlamaz. Aksine, bir çalışma alanıyla başlar ve bu alanla ilgili olanın ortaya çıkmasına izin verilir (Strauss ve Corbin, 1990, s. 23). Bundan ortaya çıkan şey, sosyal girişimlerin kimliğini söylemsel olarak inşa eden kategorilerin ortaya çıkarılmasıdır. Üst yönetim söylemlerindeki kimlik ve meşruiyet oluşturma çabalarına gömülü teori yaklaşımını uygulamak, metinlerin içeriğinde ilgili belirleyicileri aramayı gerektirmektedir.

Nitel araştırmalarda güvenirlik, zaman ve araştırmacılar arasındaki tutarlllığın bir ölçüsüdür Güvenilir bir prosedür, uygulama koşullarına bakılmaksızın aynı fenomen dizisinden aynı sonuçları vermelidir (Miles ve Huberman, 1990 Akt: Krippendorff, 1980, s. 129). LeCompte ve Goetz (1982, s. 41-42), nitel araştırmada iç güvenirliğinin sağlanması için birtakım stratejiler önermektedir. İlk olarak araştırmacı, elde ettiği verileri doğrudan, hiçbir yorum yapmadan sunmalıdır. Araştırmanın verilerinin kamera ya da ses kayıt cihazı gibi bir yere kaydedilmesi de iç güvenilirlik açısından önemlidir. LeCompte ve Goetz (1982, s. 3740), nitel araştırmada dış güvenirliğin sağlanması için önerdiği stratejileri şu şekilde sıralamıştır: İlk olarak araştırmacı araştırmadaki konumunu belirtmelidir. Veri elde edilen katılımcıların ve veri elde edilen ortamın, araştırmanın kavramsal çerçevesinin ve varsayımlarının, veri toplama ve analiz etme yönteminin ayrıntılı bir şekilde tanımlanması da nitel araştırmanın dış güvenilirliği için gerekli hususlar arasında yer almaktadır. Bu çalışmada da güvenilirliği güçlendirmek amacıyla telefon görüşmeleri kayıt alıına alınmış, tüm belgeleri kodlamak için aynı kodlama şeması kullanılmış, incelenen tüm sosyal girişimlerin verilerine aynı temalar ve kodlar uygulanmıştır. Ayrıca, hangi araştırma yöntemlerinin kullanıldığı; hangi belgelerin ve verilerin analiz edildiği açıç̧a belirtilerek çalışmanın güvenilirliği güçlendirilmiştir.

Nitel araştırmalarda geçerlik, veri içinden çıkarılan anlamlar/sonuçlar ve bu anlam ve sonuçların ne kadar objektif gerçekliği oluşturduğu ile ilgilidir (Güler vd., 2013, s. 334). Elde edilen verilerin ayrıntılı şekilde rapor edilmesi ve araştırmacının sonuçlara nasıl ulaştı̆ııı açıklaması nitel araştırmada geçerliliğin önemli ölçütleri arasında yer almaktadır (Yıldırım ve Şimşek, 2000, s. 78). İç geçerlik; bulguların anlamlı olup olmadığını, insanlar ve okuyucular için güvenilir olup olmadığını ve bunların "baktı̆̆ımız şeyin portresi" olup olmadığını belirten "doğruluk değeri" ile ilgilidir (Miles ve Huberman, 1984, s. 278). Dış geçerlik ise çalışmanın genellenebilirliği ve diğer bağlamlara aktarlabilirliği ile ilgilidir. Nitel araştırmada genelleme dolaylı yoldan yapılabilir. Diğer bir ifadeyle genellemeler; ilkeler, kurallar biçiminde değil, deneyimler ve örnekler biçimindedir (Yıldırım ve Şimşek, 2000, s. 79). Bu çalışmada araştırma süreci ve bağlamı hakkında kapsamlı bilgi verilerek, bulgular objektif ve ayrıntılı bir şekilde rapor edilerek geçerlik artırılmaya çalışılmıştır. Bu sayede başka araştırmacılar tarafindan diğer örneklerle, süreçlerle ve bağlamlarla karşılaştırma yapılabilir.

\section{Araştırmanın Amacı}

Bu araştırmanın amacı, Türkiye'de gelişmekte olan bir sektör olan sosyal girişimlerin, üst yönetim aracılı̆̆ıyla nasıl bir kimlik oluşturdukları ve örgütsel kimlik ile ne tür bir meşruiyet elde etme çabası içinde olduklarını araştırmaktır. Araştırma, şu sorulara yanıt aramayı amaçlamaktadır:

- Sosyal girişimlerin merkezi, temel ve ayırt edici özellikleri nelerdir?

- Sosyal girişimler örgütsel kimlik aracılığıyla ne tür bir meşruiyet elde etmeye çalışmaktadır?

\section{Evren - Örneklem}

Örgütsel kimliğin inşası, örgütün bulunduğu sektörün bulunduğu bağlamda gerçekleşmektedir. Bu nedenle, örgütlerin kimlik konumları sektördeki diğer örgütlerle ortak olan özelliklere göre tanımlanmaktadır. DiMaggio ve Powel'a (1983) göre gelişmekte olan sektörlerde böyle bir süreç özellikle dikkat çekicidir çünkü yaşam döngüsünün başlangıcındaki örgütsel alanlar, mevcut formlar açısından yüksek düzeyde çeşitlilik sağlarken, kurulduktan sonra daha homojen hale gelme eğilimindedirler. Diğer taraftan, gelişmekte olan sektörler, örgütsel kimliği incelemek için özellikle göze çarpan bir ortamdır, çünkü görece yeni başlayan kurumsallaşma, örgütlerin kimlik oluşum sürecini özellikle görünür kılmaktadır (Clegg vd., 2007, s. 499-500). Gelişmekte olan sektörlerde meşruiyetin yaratılması, üst yönetimin sembolik dil ve davranışı kullanma kapasitesinin yanı sıra yaptıkları hakkında tutarlı hikayeler iletme yetenekleriyle 
bağlantılıdır. Örgütsel kimliği tanımlama girişimleri, örgütün karakterini söylemsel olarak oluşturma süreçleri olarak kabul edilebilir (Clegg vd., 2007, s. 515-516).

Bu bilgilerden yola çıkarak bu çalışmanın ana kütlesini Türkiye'de faaliyet gösteren sosyal girişimler oluşturmaktadır. Araştırmanın örneklemini belirlemede amaçlı örnekleme yöntemi benimsenmiş, görüşme talebine yanit veren 13 sosyal girişim örneklemi oluşturmuştur. Türkiye'de faaliyet gösteren sosyal girişimlerin üst düzey yöneticileri ile telefon görüşmeleri yapılmıştır. Çünkü onlar sosyal girişimin geçmişi ve kimliği hakkında en alakalı bilgiye sahip olan kişilerdir. Yarı yapılandırılmış şekilde yapılan bu görüşmeler, örgütsel kimlik ve meşruiyet hakkındaki yönetsel alg1, tutum ve görüşlere ilişkin ana veri kaynağıdır. Bu tür görüşmeler, sabit seçenekli cevaplamayı ve alanda derinlemesine gidebilmeyi birleştirmektedir (Büyüköztürk, Çakmak Kilıç, Akgün, Karadeniz ve Demirel 2014, s. 152).

\section{Veri Toplama Araçları ve Verilerin Toplanması}

Görüssme soruları literatür taraması (Albert ve Whetten, 1985; Dutton ve Dukerich, 1991; Gioia ve Thomas, 1996; Fiol, Huff, ve Sarason, 1996; Elsbach ve Kramer, 1996; Clegg vd. 2007; Clegg, Kornberger, ve Rhodes, 2005; Gioia vd., 2000; Chreim, 2000) sonucunda oluşturulmuştur. Merkezlik, "misyon" “yapılan şeyin temel nedeni” gibi sorularla ölçülmüştür. D'Aveni ve MacMillan'a (1990) göre başka bir merkezilik ölçüsü, belirli bir temaya yapılan referansların sayısıdır. Bir öğeden bahsedilme sıklı̆ı bir merkezilik ölçüsüdür. Ayırt ediciliği ortaya çıkarmak için diğer sosyal girişimler ile kıyaslandığında benzer ve farklı olarak görülen özellikler; süreklilik için ise geçmişten bugüne sabit kalan, süregelen özelliklerin ne olduğu sorulmuştur.

Veri toplama süreci Ekim 2020'de başlamış, Aralık 2020'de sona ermiştir. Araştırmanın ikincil veri kaynağı sosyal girişimlere ait web sitelerinde yer alan bilgiler (misyon ifadeleri, değer tanımları, sosyal girişimin tanımına ve tarihçesine ilişkin bilgiler), sosyal girişimler ile ilgili haberler, sosyal girişimcilerle yapılan röportajlardır. Tüm bu kaynaklardan elde edilen veriler Nvivo 12 nitel veri analizi programına kaydedilerek içerik analizi yapılacaktır. İçerik analizinde veriler kodlanarak kodlar arasındaki ilişkiler saptanmakta; temalar ortaya çıkarılmakta ve ortaya konulan bulgular yorumlanarak birtakım sonuçlar ve araştırma modeli elde edilmektedir.

\section{Bulgular}

\section{Sosyal Girişimlere ve Girişimcilere Ait Bilgiler}

Türkiye'de sosyal girişimcilik faaliyetlerini aktif bir şekilde destekleyen Ashoka, SosyalUp, TÜSEV'in sosyal girişimcilik projesi için oluşturulan internet sitesi sosyalgirisim.org, sosyal girişim.com gibi oluşumların web sitelerinde yer alan sosyal girişimcilere ulaşılmaya çalışılmış, geri dönüş yapan on üç adet sosyal girişimci ile görüşmeler yapılmıştır. Aşağıda Tablo 1'de kurucuları ya da yöneticileri ile görüşme yapılan sosyal girişimlere ait bilgilere yer verilmiştir.

Tablo 1. Veri Elde Edilen Sosyal Girişimlere Ait Bilgiler

\begin{tabular}{lc}
\hline \multicolumn{1}{c}{ Sosyal Girişimin Adi } & Kurulus Yll \\
\hline Adım Adım & 2008 \\
Buğday Ekolojik Yaşamı Destekleme Derneği & 2002 \\
Givin.co & 2017 \\
Hepipet & 2016 \\
Iyimser Abla & 2017 \\
Joon & 2016 \\
Leyla'dan Sonra & 2014 \\
Mektepp & 2018 \\
Mevsimlik & 2017 \\
Önemsiyoruz & 2015 \\
Teyit & 2016 \\
Tolkido & 2016 \\
Topraktan Tabağa & 2018 \\
\hline
\end{tabular}




\section{Sosyal Girişimin Merkezi Özelliklerine İlişkin Görüşler \\ Merkezilik (AT1)}

Sosyal girişimin merkezi özelliklerini ortaya çıkarmaya dair sorulan sorular "Sosyal Misyon" (T1) ve "En Sık. Vurgulananlar" (T2) temaları altında toplanmıştır.

Tablo 2. Sosyal Girişimin Merkezi Özelliklerine İliskin Temalar ve Kodlar

\begin{tabular}{lllc}
\hline \multicolumn{1}{c}{ Ana Tema } & \multicolumn{1}{c}{ Temalar } & \multicolumn{1}{c}{ Kodlar } & Referans \\
\hline \multirow{3}{*}{$\begin{array}{l}\text { Merkezilik } \\
\text { (AT1) }\end{array}$} & \multirow{2}{*}{ Sosyal Misyon (T1) } & Çocuklara-Ë̆itime Destek (k1) & 27 \\
& & Kadı̈lar1 Güçlendirmek (k2) & 22 \\
& \multirow{2}{*}{ En S1k Vurgulananlar (T2) } & Ekolojik Yaşam1 Desteklemek (k3) & 14 \\
\hline & & Sosyal (k4) & 290 \\
& & Kadın (k5) & 128 \\
\hline
\end{tabular}

\section{Sosyal Misyon (T1)}

"Sosyal Misyon" (T1) teması "Çocuklara-Eğitime Destek" (k1), "Kadınları Güçlendirmek" (k2) ve "Ekolojik Yaşamı Desteklemek" (k3) olarak 3 adet kod içermektedir. Sosyal girişimcilerin ifadelerinden alıntılara aşağıda yer verilmiştir:

k1-Givin.co (...) “Givin Türkiye'de ve Dünyadaki bağışçllı sistemini geliştirmeyi, bu sayede de sivil toplum kuruluşlarılyla birlikte eğitime, çocuklara destek olmayı hedefliyor. Amacımız hem eğitim hem sağlık erişimindeki eşitsizliklerini ortadan kaldırabilmek.”

k2- İyimser Abla (...) "Kurumsal hediye kültüründen yola çıkarak ülkemizde kurumsal sosyal sorumluluk bilincini yaygınlaştırmayı amaçlayan Sevgi, "İyimser Abla sayesinde, özellikle kooperatif çatısı altında kadınların iş gücüne katılımını ve sürdürülebilir bir gelir modeline sahip olmalarını amaçlıyorum."

k3- Buğday Ekolojik Yasamı Destekleme Derneği (...) "Buğday Derneğinin niyeti, tek tek bireylerde ve bir bütün olarak toplumda ekolojik yaşam bilincini oluşturmak ve bu yönde modelleri hayata geçirmektir."

\section{En S1k Vurgulananlar (T2)}

"En Sık Vurgulananlar" (T2) teması "Sosyal" (k4), "Kadın" (k5) olarak 2 adet kod içermektedir. Sosyal girişimcilerin ifadelerinden alıntılara aşağıda yer verilmiştir:

k4- Adım Adım (...) "kendinden başka biri için, bir sosyal sorun için harekete geçmesi..."

k5- İyimser Abla (...) "Kadın kooperatifleri, 'İyimser Abla' ile güçleniyor."

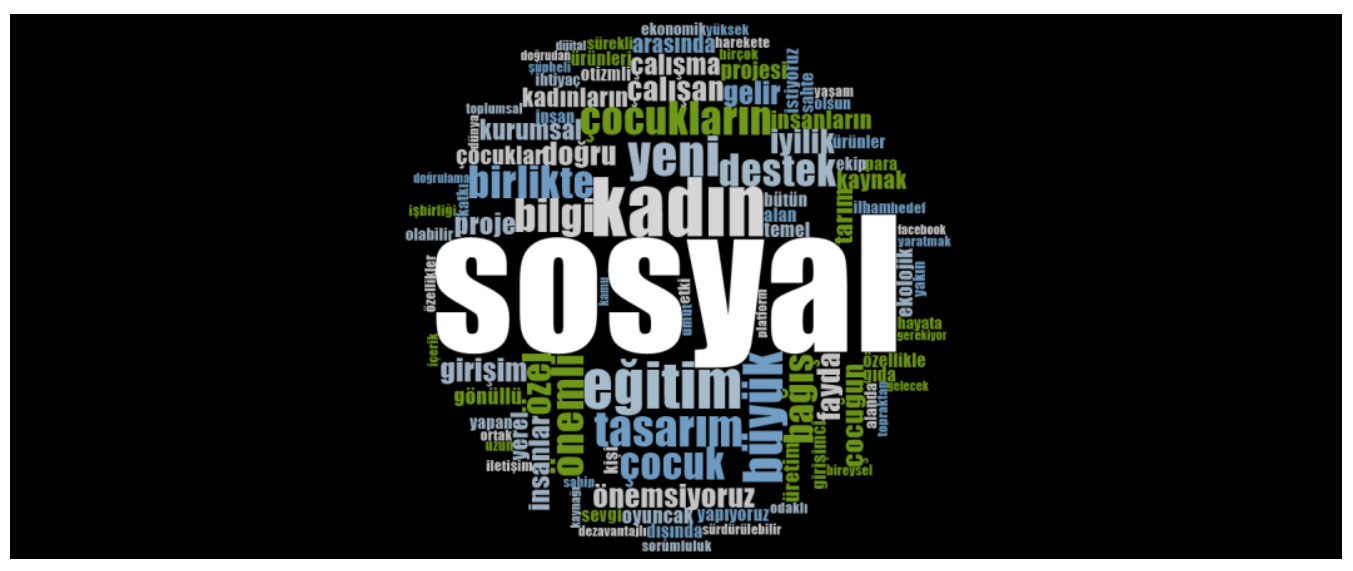

Şekil 1. En Sık. Vurgulanan Kelimelere Ait Kelime Bulutu Görünümü 


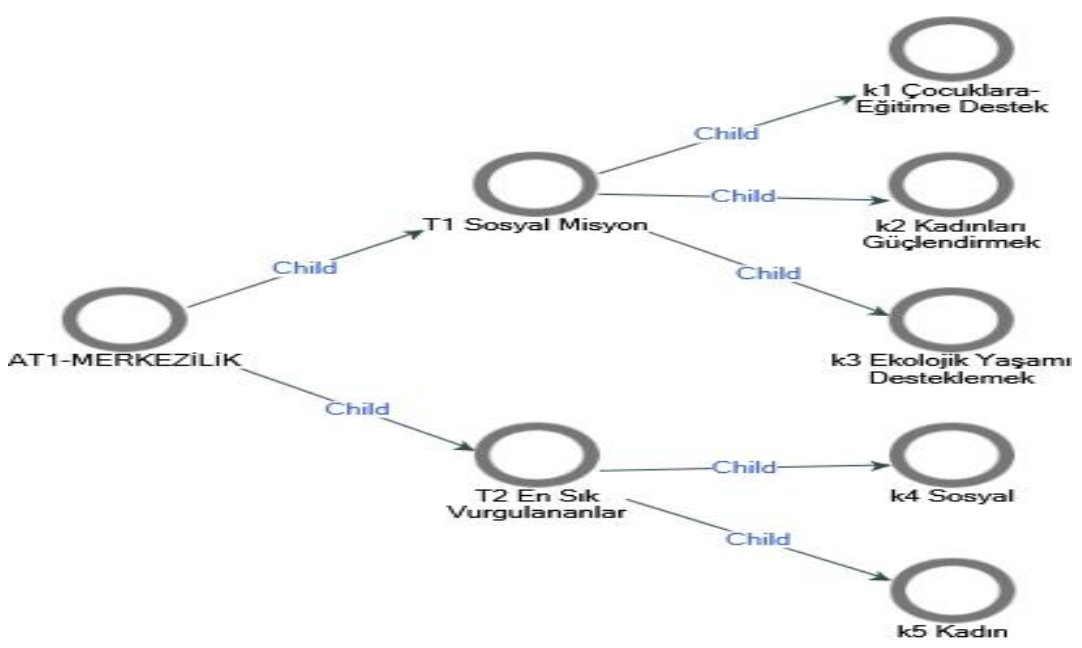

Şekil 2. Merkeziligüe Iliskkin Tema ve Kodlar NVivo Modeli-1

\section{Sosyal Girişimin Farklı Özelliklerine İlişkin Görüşler Farklı1ık (AT2)}

Sosyal girişimin farklıllğına dair sorulan sorular "Ayurt Edici Özellikler" (T3) ve "Benzer Özellikler" (T4) temaları altında toplanmıştır.

Tablo 3. Sosyal Girişimin Farkhliğgna İlişkin Temalar ve Kodlar

\begin{tabular}{cllc}
\hline Ana Tema & \multicolumn{1}{c}{ Temalar } & \multicolumn{1}{c}{ Kodlar } & Referans \\
\hline \multirow{3}{*}{ Farkl111k (AT2) } & \multirow{2}{*}{ Ayırt Edici Özellikler (T3) } & Samimiyet (k6) & 10 \\
\cline { 2 - 4 } & \multirow{2}{*}{ Benzer Özellikler (T4) } & Kapsayıcllk (k7) & 6 \\
\cline { 2 - 4 } & & Sosyal Fayda (k8) & 9 \\
\hline
\end{tabular}

\section{Ayırt Edici Özellikler (T3)}

"Ayırt Edici Özellikler" (T3) temas1 "Samimiyet" (k6) ve "Kapsayıcllık" (k7) olarak 2 adet kod içermektedir. Sosyal girişimcilerin ifadelerinden alıntılara aşağıda yer verilmiştir:

k6- Joon (...) "Biz tasarımın erişilebilir bir şey olduğunu anlatmaya çalışıyoruz. O yüzden fiyatlandırma politikamızda vs. de de daha alım gücünü gözetiyoruz. Bunun dışında insanların kaliteli bir şey alabileceği, buraya geldiğinde o kalitenin olduğu, iyi işin, kaliteli işin olduğu. İyi tasarım dememizin sebebi de o. Nitelikli işin burada bulunabileceğini hissettirmeye çalsşıyoruz. Renklerimizde de biraz daha soft tonlar seçmemizin nedeni o samimiyetin, içtenliğin yansıtılmaya çalısıllmasıdır. Çok havalı bir marka olmaya çalışmiyoruz."

k7- Tabaktan Toprağa (...) "Türkiye de sosyal girişimler bir tek işe yoğunlaşıyor. Biz öyle değiliz her kesimden insanı bu işe katmak zorundayız. Yerel kalkınma demek bu demek. Ben sadece sabun üretiyorum ve sabun üretenleri alıyorum diye bir şey yok. Sadece tek kesimde yapamazsınız üretimin her kesimini ayağa kaldırmak zorundasınız. Amaç bir tabak yapmak değil artık. Tabağın sürdürülebilirliğini sağlamak."

\section{Benzer Özellikler (T4)}

"Benzer Özellikler" (T4) temas1 "Sosyal Fayda" (k8) ve "Organik Örgüt Yapıs1" (k9) olarak 2 adet kod içermektedir. Sosyal girişimcilerin ifadelerinden alıntılara aşağıda yer verilmiştir:

k8- Mevsimlik (...) "Sosyal girişimlerin tamamı çok iyi niyetle, sosyal fayda sağlamak için, toplumdaki belirli bir alandaki yaraya merhem olalım diye bir el atma amacındalar. Ortak özelliğimiz sosyal fayda sağlamak sanırım." olabilir.'”

k9- Teyit (...) "Hiçbir sosyal girişim katı hiyerarşik yapılar değildir mesela. Bu ortak özelliklerden biri 


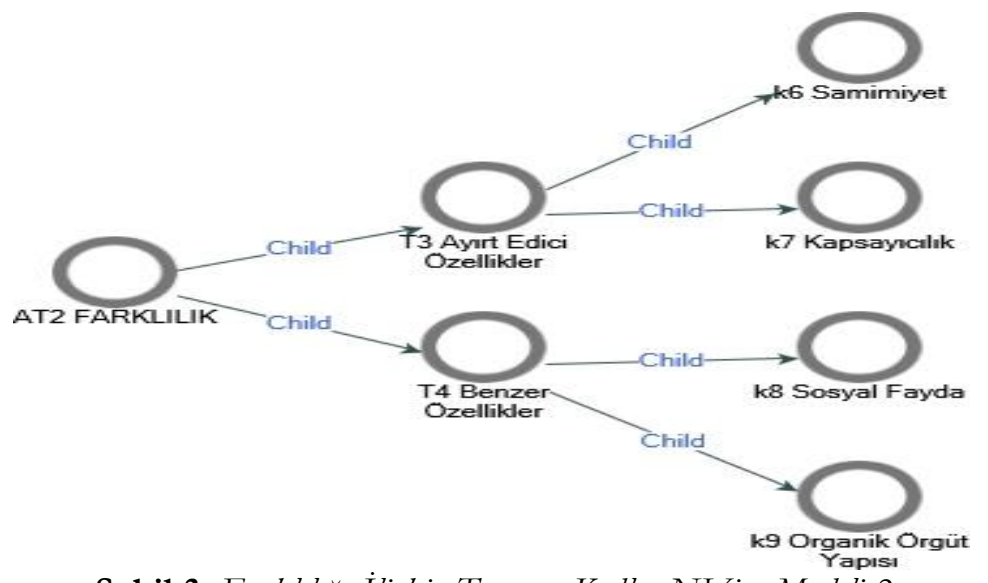

Şekil 3. Farklulŭga İlişkin Tema ve Kodlar NVivo Modeli-2

\section{Süreklilik (AT3)}

Sosyal girişimin sürekliliğine dair sorulan sorular "Süregelen Özellikler" (T5) temas1 altında toplanmıstır.

Tablo 4. Sosyal Girişimin Sürekliliğine Illiskin Temalar ve Kodlar

\begin{tabular}{cclc}
\hline \multicolumn{1}{c}{ Ana Tema } & \multicolumn{1}{c}{ Temalar } & \multicolumn{1}{c}{ Kodlar } & Referans \\
\hline \multirow{3}{*}{ Süreklilik (AT3) } & \multirow{2}{*}{ Süregelen Özellikler (T5) } & Paylaşım (k10) & 11 \\
& & Yenilik (k11) & 9 \\
\hline
\end{tabular}

\section{Süregelen Özellikler (T5)}

"Süregelen Özellikler" (T5) teması "Paylaşım" (k10) ve "Yenilik" (k11) ve "İyilik" (k12) olarak 3 adet kod içermektedir. Sosyal girişimcilerin ifadelerinden alıntılara aşağıda yer verilmiştir:

k10-Mektepp (...) “Öğretmenlerin kendi arasında bir paylaşım kültürü oluşturmasını istiyoruz. Yani bu açık kaynak paylaşım alanı dediğimiz konuyu eğitim alanında da herkesin benimsemesi, herkesin birbirleriyle birşeyler paylaşarak birbirlerine katkı sağlamasını, birbirinden öğrenmesini ve bu şekilde toplu bir gelişmeye ulaşmayı hedefliyoruz. Bu kapsamda mektepp.com da dijital bir platform oluşturduk. Burada onlara aslında bir alan sağlıyoruz. Dijital olarak etkinliklerini paylaşmalarını."

k11- Tolkido (...) "Sosyal heaker/inovatif bir girişimiz. Bizim kullandığımız yazılımlar, donanımlar ufak maliyetlerle zekice düşünülmüş ama inovatif fikirler."

k.12- Givin (...) "Givin bir mobil uygulama. Herhangi bir eşyamızı ya da yeteneğimizi STKlara destek olmak için satışa sunuyoruz. Aynı zamanda yaptığımız bütün alışverişlerin, bütün ödemelerin geliri, eğitim için çalışan TEGEV, Toplum gönüllüleri, koruncuk vakfi, tohum otizm vakfı gibi çok değerli stk'lara gidiyor. Dolayısıyla "alışverişin en iyi hali" diyoruz givin için."

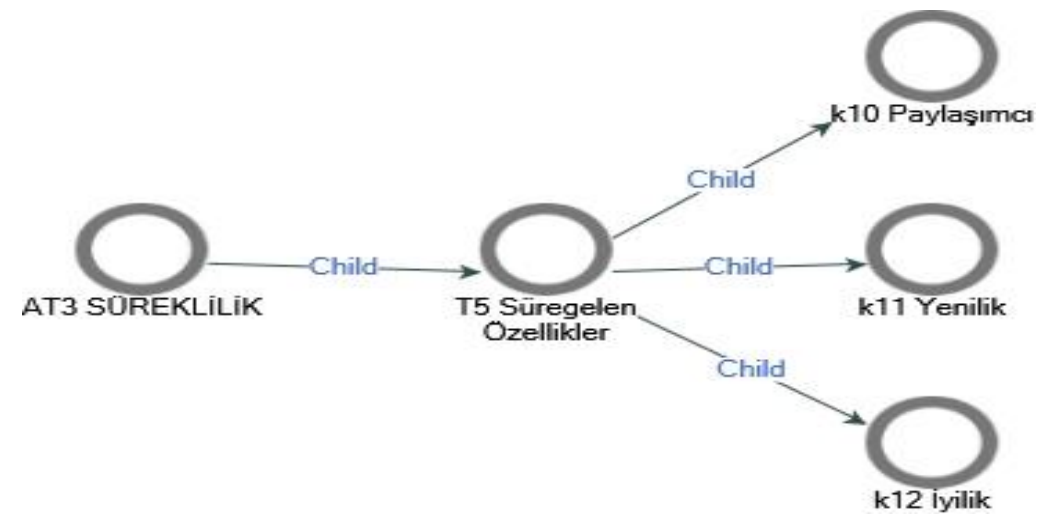

Şekil 4. Sürekliliğe Ilişkin Tema ve Kodlar NVivo Modeli-2 


\section{Meşruiyet (AT4)}

Sosyal girişimin meşruiyeti "Bilişsel Meşruiyet" (T6) ve "Ablaki Meşrniyet" (T7) temaları altında toplanmıştır.

Tablo 5. Sosyal Girişimin Meşruiyetine Ilişkin Temalar ve Kodlar

\begin{tabular}{cllc}
\hline Ana Tema & \multicolumn{1}{c}{ Temalar } & Kodlar & Referans \\
\hline \multirow{4}{*}{ Meşruiyet (AT4) } & Bilişsel Meşruiyet (T6) & Sosyal Fayda (k13) & 59 \\
\cline { 2 - 4 } & & Şeffaflı (k14) & 18 \\
& \multirow{2}{*}{ Ahlaki Meşruiyet (T7) } & Adil Olma (k15) & 8 \\
& & Hesap Verebilirlik (k16) & 7 \\
\hline
\end{tabular}

\section{Bilişsel Meşruiyet (T6)}

"Bilişsel Meşruiyet" (T6) teması "Sosyal Fayda" (k13) şeklinde 1 adet kod içermektedir. Sosyal girişimcilerin ifadelerinden alıntılara aşağıda yer verilmiştir:

k13- Hepipet (...) "Para kazanmak asla değil. Elde edilen gelir doğrudan mama alımı için kullanıllyor. Adıyaman'da, Kars'da, Van'da bir hayvana faydalı olabiliyorsam, o hayvan benim sayemde sağlığına kavuşabiliyorsa bunu karşılığını hiçbir zaman maddi olarak koymamıştım. Bu motivasyon ve mutluluk benim için yeterli."

k13- Leyla'dan Sonra (...) "Bizi yönlendiren ana etmen daha çok çocukla tanışabilmek, daha çok çocuğun hayatına dokunabilmek ve elimizden geldiğince her çocuktan bir dilek gerçekleştirebilmek."

\section{Ahlaki Meşruiyet (T7)}

"Ahlaki Meşruiyet" (T7) teması "Şeffaflık" (k14), “Adil Olma” (k15) ve "Hesap Verebilirlik" (k16) olarak 3 adet kod içermektedir. Sosyal girişimcilerin ifadelerinden alıntılara aşağıda yer verilmiştir:

k14- Joon (...)"Bir tanesi şeffaflık. Bir teklif gönderirken bile para nereye gidiyor kime gidiyor? Malzeme kimden alınıyor, kime veriliyor vs. her zaman çok şeffaf oluyoruz. Kendi içimizde de, ekip içinde de oldukça şeffafiz."

k15- Buğday Ekolojik Yaşamı Destekleme Derneği (...) "Eylemlerinde adil değer yaratmay1 esas alır. El değiştirmesi sırasında döngünün her aşamasında bireylerin ve doğa unsurlarının zarar görmediği bir ticaret anlayışını destekler."

k16- Önemsiyoruz (...) “ Hesap verebilir ve şeffaf olmak değerlerimizin en başında geliyor.”

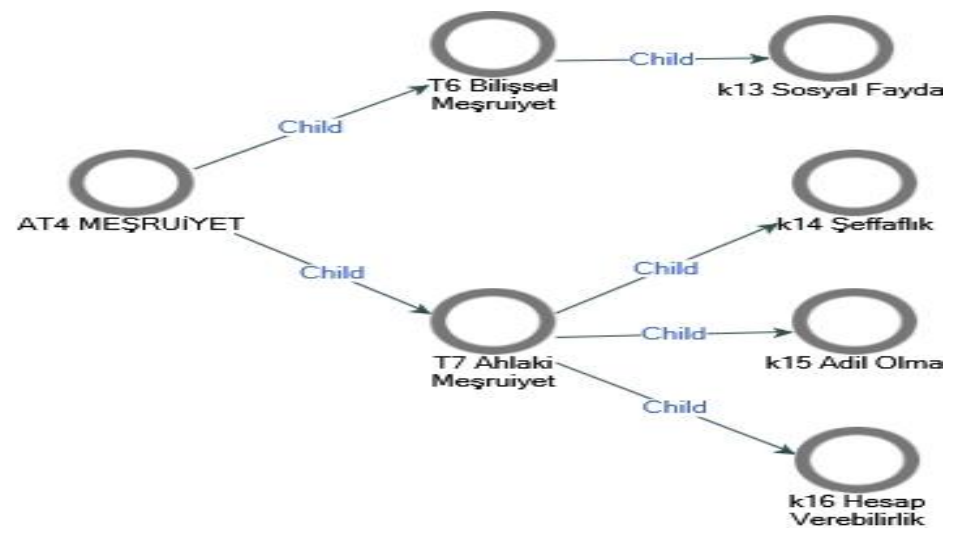

Şekil 5. Mesrriyete İliskin Tema ve Kodlar NVivo Modeli-2

\section{Tartışma, Sonuç ve Öneriler}

Çalışmada, Türkiye'de gelişmekte olan bir sektör olan sosyal girişimlerin, üst yönetim aracillğıyla meşru bir kimlik oluşturmak için ne tür bir çalışma şekli ve dolayısıyla oluşturulan örgütsel kimlik ile ne tür bir meşruiyet kazanma çabası içinde oldukları araştırılmıştır. Örneklemde yer alan sosyal girişimlerin merkezi özelliklerinin "sosyal misyon" teması altında toplandığı görülmüştür. Sosyal misyonun içeriğine bakıldığında daha çok çocukların ve kadınların desteklenmesine yönelik faaliyetlerden oluştuğu belirtilebilir. Merkezi özellikler temasını desteklemek amacıyla en sık vurgulanan kelimeleri saptamak amacıyla kelime frekansı (Word Frequency) analizi yapılmışır. Analiz sonucunda sosyal misyon temasını 
destekler nitelikte en sık vurgulanan kelimelerden birinin "kadın" bir diğerinin ise "sosyal" kelimesi olduğu görülmektedir. Sosyal girişimlerin merkezilik tanımlarında sosyal misyonu belirtmeleri McMillan'ın (1987) ve Carpenter'in (1994) aynı sektörde faaliyet gösteren örgütlerin kimlik beyanlarının yaptıkları iş, misyon ve sektörün özellikleri ile yakından ilgili olduğuna dair ifadeleri ile tutarlıdır.

Örneklemde yer alan sosyal girişimlerin ayırt edici özelliklerinin "samimiyet" ve "kapsayıcıllk" ile ifade edildiği görülmüştür. Sosyal girişimlerin kendilerini diğer sosyal girişimlerden ayırmak için kullandıkları özellikler aynı kavramlar etrafında toplanmıştır. Bu kavramlar toplumda sosyal fayda yaratmak üzerine inşa edilen sosyal girişimler için şaşırtıcı değildir. Martin vd. de (1983) benzersiz olduğunu iddia eden yedi tür öykü üzerinde yaptıkları çalışmada, bu tür öykülerin çeşitli örgütlerde aynı biçimde ortaya çıktı̆ııı göstermişlerdir. Dolayısıyla araştırmanın sonuçları Martin vd. (1983)'nin araştırmasının sonuçları ile paralellik göstermektedir. Sosyal girişimlerin benzer özelliklerinin ise "sosyal fayda" ve "organik örgüt yapısı" ile tanımlandığı saptanmıştır. Bu sonuçlar da yine sosyal girişimlerin kendilerine has yapılarını vurgulamaktadır. Analiz sonucunda sosyal girişimlerin süregelen özellikleri "paylaşım", "yenilik" ve "iyilik" gibi kavramlar altında toplanmıştır. Bu kavramların kelime frekansı analizinde de öne çıkan kavramlar arasında yer aldığını görebiliriz. Bu sonuçlar Cheriem (2000) ve Clegg vd.'nin (2007) araştırma sonuçları ile tutarlıdır.

Çalışmanın meşruiyet ile ilgili sonuçlanına bakıldığında sosyal girişimlerin meşru bir örgüt kimliği inşa etmelerinin daha çok "bilişsel meşruiyet" ve daha sonra "ahlaki meşruiyet" elde etmelerine yarar sağlayacağı saptanmıştır. Bilişsel meşruiyet açısından sosyal fayda özelliğinin; ahlaki meşruiyet açısından ise şeffaflık, adil olma ve hesap verebilirlik gibi etik değerlerin öne çıkarıldığı görülmektedir. Clegg vd. (2007, s. 515-516) ve Bridwell-Mitchell ve Mezias da (2012, s. 205) yeni kimliklerin oluşumunda bilişsel meşruiyet stratejilerinin daha uygun olduğunu çünkü örgütsel kimliğin esasen örgüt faaliyetleri için bir dizi tanım ve anlam içerdiğini ifade etmişlerdir.

Bu çalışma Türkiye'de sosyal girişimcilik örgütsel alanında örgütsel kimliğin ve örgütsel kimlik aracılığıyla meşruiyet elde etme çabalarının anlaşılması açısından önemli çıkarımlara sahip olmasına rağmen bazı sınırlılıkları da bulunmaktadır. Veriler sosyal girişimlerin üst yönetimi ile yapılan görüşmelerden ve ikincil veri kaynaklarında yer alan bilgilerden elde edilmiştir. Diğer paydaşları veya örgüt üyeleri analize dahil edilmemiştir. Bu nedenle, mevcut araştırma sonuçları değerli olsa da kimliklerin ilişkisel inşasına ve farklı paydaşlardan gelen görüşlere 1şık tutan daha fazla çalışmaya ihtiyaç vardır. Ayrıca gelecekteki araştırmalarda örgütlerin zaman içindeki kimlik değişimlerini (He ve Baruch, 2009, s. 595), keşfedecek çalışmaların yapılmasının yararlı olacağı düşünülmektedir. Araştırma sonuçları açısından, örgütsel kimliğin sosyal girişimlerin meşruiyet elde etmelerindeki rolü düşünüldüğünde, bu durumun örgütteki yöneticiler tarafindan dikkate alınması önemli hale gelmektedir. Scott ve Lane (2000) ile Pratt ve Foreman'ın (2000) da belirttiği gibi yöneticiler örgütü diğer örgütlerden ayıran misyonlar, uygulamalar ve değerler yoluyla örgütsel kimliklerini şekillendirebilir ve örgütsel kimlik aracllyyla örgütün kurumsal çevrede bir meşruiyet elde etmesine katkı sağlayabilirler.

Aşağıda Şekil 6'da araştırmanın model önerisi yer almaktadır.

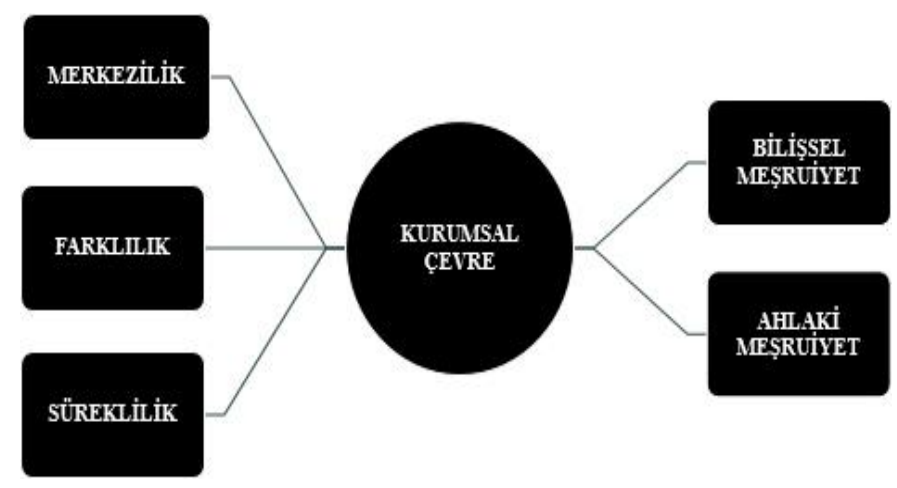

Şekil 6. Araștırmann Model Önerisi 


\section{Etik Beyan}

"Sosyal Girişimlerin Örgütsel Kimlik Yoluyla Meşrniyet Arayışlarn" başlıklı çalışmanın verileri 2020 ekim-aralık ayları arasında toplanmıştır. Makalenin yazım sürecinde bilimsel kurallara, etik ve alıntı kurallarına uyulmuş; toplanan veriler üzerinde herhangi bir tahrifat yapılmamış ve bu çalışma herhangi başka bir akademik yayın ortamına değerlendirme için gönderilmemiştir. Ayrıca Hakkari Üniversitesi Bilimsel Araştırma ve Yayın Etiği Kurulu'ndan 14/10/2020 tarih ve 2020/26 karar sayılı etik kurul izni alınmıştır.

\section{Kaynakça}

Albert, S. ve Whetten, D. A. (1985). Organizational identity. In L. L. Cummings ve B. M. Straw (Eds.), Research in organizational behaviour (pp. 263-295). Greenwich: JAI Press.

Aldrich, H. ve Fiol, C. M. (1994). Fools rush in? The institutional context of industry creation. Academy of Management Review, 19(4), 645-670. doi: https://doi.org/10.2307/258740

Ağlargöz, O. (2011). Anadolu üniversitesi iktisadi ve idari bilimler fakültesi ve mühendislik-mimarllk fakültesi örgütsel kimliklerinin fenomenografik durum çalısmalaryla analizi (Doktora Tezi). Anadolu Üniversitesi, Sosyal Bilimler Enstitüsü, Eskişehir.

Ashforth, B. ve Mael, F. (1996). Organizational identity and strategy as a context for the individual. In J. A. C. Baum ve J. E. Dutton (Eds.) Advances in the strategic management (pp. 19-64), Greenwich: JAI Press.

Balmer, J. M. T. (1994). The BBC's corporate identity: Myth, paradox and reality. Journal of General Management, 19, 3347. Doi: https://doi.org/10.1177/030630709401900303

Bitektine, A. ve Haack, P. (2015). The macro and the micro of legitimacy: Towards a multi-level theory of the legitimacy process. Academy of Management Review, 40(1), 49-75. Doi: https://doi.org/10.5465/amr.2013.0318

Blau, P. ve Scott, R. (1962). Formal organizations. Scranton: Chandler Publishing Company.

Bridwell-Mitchell, E. N. ve Mezias, J. S. (2012). The quest for cognitive legitimacy: Organizational identity crafting and internal stakeholder support. Journal of Change Management, 12(2), 189-207. Doi: http://dx.doi.org/10.1080/14697017.2011.645053

Brown, A. D. (2001). Organization studies and identity: Towards a research agenda. Human Relations, 54(1), 113-121. doi: https://doi.org/10.1177/0018726701541014

Brunninge, O. (2005). Organizational self- understanding and the strategy process (Doctoral Dissertation). Strategy Dyanamics in Scania and Handelsbanken. Jönköping: JIBS

Büyüköztürk, Ş., Çakmak Kılıç E., Akgün, Ö. E., Karadeniz, Ş. ve Demirel, F. (2014). Bilimsel araştırma yöntemleri. Ankara: Pegem Akademi Yayınları.

Carpenter, M. A. (1994). Organizational identity and strategic decision making: The decision to divest. Paper Presented at the Annual Meeting of the Academy of Management. Dallas.

Cheney, G. (1991). Rhetoric in an organizational society: Managing multiple identities. Columbia: University of South Carolina Press.

Chreim, S. (2000). The evolution of organizational identity: $A$ discursive study (Doctoral Dissertation). École des Hautes Études Commerciales, Montreal.

Clegg, S. R., Kornberger, M. ve Rhodes, C. (2005). Learning/ becoming/organizing. Organization, 12(2), 147-168. doi:10.1177/1350508405051186

Clegg, S. R., Rhodes, C. ve Kornberger, M. (2007). Desperately seeking legitimacy: Organizational identity and emerging industries. Organization Studies, 28(4), 495-513. doi: https://doi.org/10.1177/0170840606067995

Corley, K. G. (2004). Defined by our strategy or our culture: Hierarchical differences in perception of organizational identity and change. Human Relations, 57(9), 1145-1177. doi: : 10.1177/0018726704047141

Corley, K., Harquil, C. V., Pratt, M., Glynn, A., Fiol, C. M. ve Hatch, M. J. (2006). Guiding organizational identity through aged adolescence. Journal of Management Inquiry, 15(2), 85-99. doi: https://doi.org/10.1177/1056492605285930

DiMaggio, P. J. ve Powell, W. W. (1983). The iron cage revisited: institutional isomorphism and collective rationality in organizational fields. American Sociological Review, 48(2), 147-160. doi: https://doi.org/10.2307/2095101

Dutton, J. E. ve Dukerich, J. M. (1991). Keeping an eye on the mirror: Image and identity in organizational adaptation. Academy of Management Journal, 34(3), 517-554. doi: https://doi.org/10.5465/256405

Eisenhardt, K. M. (1989). Building Theories from Case Study Research. Academy of Management Review, 14(4), 532-550. doi: https://doi.org/10.2307/258557

Elsbach, K. ve Kramer, R. (1996). Members response to organizational identity threats: Encountering and countering the business week rankings. Administrative Science Quarterly, 41(3), 442-476. doi: https://doi.org/10.2307/2393938

Elsbach, K. ve Sutton, R.I. (1992). Acquiring organizational legitimacy through illegitimate actions: A marriage of institutional and impression. Management Theories, 35(4), 699-738. doi: https://doi.org/10.2307/256313

Fiol, M., Huff, A. ve Sarason, Y. (1996). Operationalizing a new definition of organizational identity: Beyond central, distinctive and enduring. Paper presented at the Identity III Conference. Utah.

Foreman, P. ve Whetten, D. (2002). Members' identification with multiple- identity organizations. Organization Science, 13(6), 618-635. doi: https://doi.org/10.1287/orsc.13.6.618.493 
Gioia, D., Majken S. ve Kevin G. C. (2000). Organizational identity, image, and adaptive instability. Academy of Management Review, 25(1), 63-81. doi: https://doi.org/10.2307/259263

Glaser, B. ve Strauss, A. (1967). Discovery of grounded theory. Aldine: Chicago, IL.

Glynn, M. A. ve Abzug, R. (2002), Institutionalizing identity: Symbolic isomorphism and organizational names. Academy of Management Journal, 45(1), 267-80. doi: https://doi.org/10.2307/3069296

Güler, A., Halıcıoğlu, M. B. ve Taşğın, S. (2013). Sosyal bilimlerde nitel araştırma yöntemleri. Ankara: Seçkin Yayıncılık.

He, H. ve Baruch, Y. (2009). Transforming organizational identity under institutional change. Journal of Organizational Change Management, 22(6), 575-599. doi: 10.1108/09534810910997014

Johnson, J. ve Holub, M. J. (2003). Questioning organizational legitimacy: The case of U.S. expatriates. Journal of Business Ethics, 47, 269-293. Stable URL: http://www.jstor.org/stable/25075143

LeCompte, M. D. ve Goetz, J. P. (1982). Problems of reliability and validity in ethnographic research. Review of Educational Research, 52, 31-60. doi: https://doi.org/10.3102/00346543052001031

Lounsbury, M. ve Glynn, M. A. (2001). Cultural entrepreneurship: Stories, legitimacy, and the acquisition of resources. Strategic Management Journal, 22(6/7), 545-64. doi: https://doi.org/10.1002/smj.188

Levitt, B. ve Nass, C. (1994). Organizational narratives and the person/identity distinction. Annals of the International Communication Association, 17(1), 236-246. doi: https://doi.org/10.1080/23808985.1994.1167886

Martin, J., Feldman, M. S., Hatch, M. J. ve Sitkin, S. (1983). The uniqueness paradox in organizational studies. Administrative Science Quarterly, 28, 438-453. doi: https://doi.org/10.2307/2392251

McMillan, J. J. (1987). In search of the organizational persona: A rationale for studying organizations rhetorically. In L. Thayer (Ed.), Organization communication: Emerging perspectives II (pp. 21-45). Norwood, NJ: Ablex

Miles, M. B. ve Huberman, A. M. (1984). Qualitative data analysis: A sourcebook of new methods. California: Sage Publication.

Pfeffer, J. ve G. R. Salancik. (2003). The external control of organizations: A resource dependence perspective. California: Stanford University Press.

Pratt, M. G. ve Foreman, P. O. (2000). Classifying managerial responses to multiple organizational identities. The Academy of Management Review, 25(1), 18-42. doi: https://doi.org/10.2307/259261

Scott, S. G. ve Lane, V. R. (2000). A stakeholder approach to organizational identity. The Academy of Management Review, 25(1), 43-62. doi: https://doi.org/10.2307/259262

Scott, W. R. (2001). Institutions and organizations. Newbury Park: Sage Publications.

Selznick, P. (1957). Leadership in administration. New York: Harper \& Row.

Sillince, J. A. A. ve Brown, A. D. (2009). Multiple organizational identities and legitimacy: The rhetoric of police websites. Human Relations, 62(12), 1829-1856. doi: https://doi.org/10.1177/0018726709336626

Strauss, A. ve Corbin, J. (1990). Basics of qualitative research: Grounded theory procedures and techniques. London: Sage Publications.

Strauss, A. ve Corbin, J. (1998). Basics of qualitative research: Techniques and procedures for developing grounded theory. London: Sage Publications.

Suchman, M. C. (1995). Managing legitimacy: Strategic and institutional approaches. The Academy of Management Review, 20(3), 571-610. doi: https://doi.org/10.2307/258788

Thoger Christensen, L. ve Cheney, G. (1994) Articulating identity in an organizational age. Annals of the International Communication Association, 17(1), 222-235. doi: https://doi.org/10.1080/23808985.1994.11678885

Whetten, D. A. ve Godfrey, P. C. (1998). Identity in organizations: Building theory through conversations. Foundations for organizational science. London: A Sage Publications Series.

Whetten, D. A. ve Mackey, A. (2002). A social actor conception of organizational identity and its implications for the study of organizational reputation. Business and Society, 41(4), 393-414. doi: https://doi.org/10.1177/0007650302238775

Whetten, D. A. (2006). Albert and Whetten revisited: Strengthening the concept of organizational identity. Journal of Management Inquiry, 15(3), 219-234. doi: https://doi.org/10.1177/1056492606291200

Yıldırım, A. ve H. Şimşek. (2000). Sosyal bilimlerde nitel araştırma yöntemleri. Ankara: Seçkin Yayıncılık.

\section{EXTENDED ABSTRACT}

The identity of an organization is formed in the context in which it operates. According to Albert and Whetten (1985), organizational identity is the most central, distinctive and enduring characteristics perceived by the members of an organization about the organization. Identity legitimacy of the organization in the institutional environment is determined by compliance with corporate norms, values and regulations (He, \& Baruch, 2009, p. 592). Organizational identity remains an implicit theme in the institutional theory literature, and limited number of research has been conducted on the identity attributes associated with legitimacy. Therefore, it is an important area that deserves further research. Research has often focused on identity as an enduring core that defines the organization. Although the word 'identity' is not used, discussions of institutional theory (DiMaggio, \& Powell, 1983) have drawn attention to identity in terms of how organizations define themselves in relation to other organizations. 
Just like people, organizations also work according to an established order. Otherwise, the identity they defend will not make sense. Where such order is not established, as in emerging sectors, organizations must build order for themselves (Aldrich, \& Fiol, 1994, p. 648). Lounsbury and Glynn (2001) state that the identity of a new entrepreneurial organization can serve as a cornerstone of legitimacy that can be given by various stakeholders (He, \& Baruch, 2009, p. 592). On the other hand, lack of legitimacy of the organizational identity may pose the risk of not being understood or approved by the social environment. Based on this, the aim of the study of social enterprises in Turkey, is to reveal the patterns of organizational identity and that they are investigating in an effort to obtain a kind of legitimacy with through organizational identity.

The data obtained from interviews with thirteen social entrepreneurs were analyzed in NVivo 12 qualitative data analysis program. The results show that the central characteristics of the social enterprises in the sample are gathered under the social mission theme. Looking at the content of the social mission, it can be stated that it consists of activities aimed at supporting children and women. "Word Frequency" analysis was conducted to identify the most frequently emphasized words in order to support the central features theme. As a result of the analysis, it has been determined that one of the most frequently emphasized words supporting the social mission theme is "woman" and the other is "social".

It was observed that the distinctive features of social enterprises in the sample were expressed in terms of "sincerity" and "inclusiveness". The characteristics that social enterprises use to distinguish themselves from other social enterprises are gathered around the same concepts. These emerging concepts are not surprising for social enterprises built on creating social benefit in society. Martin et al. (1983), in their study of seven types of stories claiming to be unique, showed that such stories appeared in the same way in various organizations. It has been determined that similar characteristics of social enterprises are defined by "social benefit" and "organic organizational structure". These results also highlight the unique nature of social enterprises. As a result of the analysis, the ongoing characteristics of social enterprises were collected under concepts such as "sharing", "innovation" and "goodness". Considering the results of the study regarding legitimacy, it was determined that social enterprises establishing a legitimate organizational identity would be more beneficial for gaining "cognitive legitimacy" and then "moral legitimacy". Social benefit feature has been highlighted in terms of cognitive legitimacy. This means that the perceptions of different stakeholders about social enterprises are desired to be based on social benefit. In terms of moral legitimacy, it is seen that ethical values such as transparency, fairness and accountability were emphasized. Moral legitimacy includes the value judgments that determine the identity of the organization and its character that differs from other organizations, as well as shared by all employees.

This study has important implications for understanding organizational identity in the organizational field of social entrepreneurship and efforts to gain legitimacy through organizational identity in Turkey. But it also has some limitations. The data were obtained from interviews with the top management of social enterprises and information contained in secondary data sources. Other stakeholders or organization members were not included in the analysis. Therefore, while current research results are valuable, more studies are needed that shed light on the relational construction of identities and opinions from different stakeholders. In addition, it is thought that it will be useful to conduct studies that will explore the identity changes of organizations over time in future research. In terms of research results, considering the role of organizational identity in gaining legitimacy for social enterprises, it becomes important to consider this situation by the managers in the organization. Managers can shape their organizational identity through the missions, practices and values that distinguish the organization from other organizations and contribute to the organization's legitimacy in the institutional environment through organizational identity. 